\title{
The Authoritarian Temptation, and Its Radical Left Expressions
}

\author{
Laurence Whitehead | ORCID: 0000-0002-1088-9806 \\ Senior Research Fellow, Department of Politics and International Relations, \\ Nuffield College, University of Oxford, Oxford, UK \\ laurence.whitehead@nuffield.ox.ac.uk
}

\begin{abstract}
No political regime can be entirely immune from authoritarian temptations. This article focuses on the distinctive sources and dynamics that apply to post-revolutionary regimes. To prevail in bringing about radical and irreversible change they will require an effective security apparatus that overcomes the backlash that will arise from the previous order. These security requirements provide the first source of authoritarian temptation, but there are three more. Once the regime is firmly established the new rulers can choose what restraints on their conduct to accept. It is tempting to dispense with healthy channels of feedback. Moreover, even the most successful of revolutionary regimes polarise opinion between the old order and the new. And when material hardships arise loyalty may be rewarded above market rationality. In conjunction these amount to a serious set of authoritarian temptations.But there are also some countervailing considerations. A durably successful radical regime must counterbalance the requirements for unity and discipline against the need for creativity and adaptability. Initial emancipatory ambitions may be updated and renewed in order to inspire future generations and legitimise the revolutionary process. Such regimes can seesaw between authoritarian and empowering tendencies, rather than relying on repression alone to keep them in existence. Their legitimation strategy will contain three main components: i) reaffirming and updating their emancipatory origins; ii) downplaying/excusing any authoritarian "deviations"; iii) projecting future prospects for inclusionary development.
\end{abstract}

\section{Keywords}

radical left - authoritarian temptations - polarisation - reactionary backlash protection of rights 
Authoritarian ideas and practices are widely distributed across the left/right political spectrum. The simplest exercise is to list the most flagrant and spectacular expressions of this outlook on the two extremes, and to demonstrate how far they resemble each other and how eager they are to dramatize the us/ them polarity that both divides and sustains them. This historical pattern is so reliable and recurrent that it should always figure prominently in any overall assessment of the politics of intolerance and repression. Still, it is only one element in a more complex and challenging panorama. Extreme centrists can also opt for highly authoritarian solutions when confronted by strong challengers from right and left. Major components of the Vichy regime were drawn from shall we say the "center-right", rather than the extreme right, and Benito Mussolini was able to draw on "center-left" recruits in 1920s Italy. Beyond these examples of centrist collapse in the face of polarization from without, we can also identify cases of both conservative and reformist political movements that swerved into authoritarianism rather than accept that their projects were faltering. Raycep Tayyip Erdogan and Juan Domingo Peron provide relevant illustrations. Lastly, even apparently respectable centrist leaders can also lapse into authoritarian ways of perpetuating themselves after too long in control. The half century of Christian Democrat dominance in Italy involved systemic corruption and long-term entanglement with the Mafia, despite their ostensible moderation and supposed commitment to liberal democracy. In short, although the most flagrant examples of unrestrained repressive rule are found on the ideological extremes, authoritarian temptations pose dangers to all shades of political opinion. In some ways the effects on moderates are more scandalous than the excesses of radicals, in that they are so suffused with hypocrisy and bad faith. Whereas regimes at the ideological poles can be openly repressive, with their imprisonments and their political persecutions, extreme moderates can betray liberty more surreptitiously, through indulgence of irresponsible elites and complicity with abusive justice systems that shelter organized crime.

Nowlet us turn the spotlight more specifically on the radical left. That phrase requires a brief introduction. It would be possible to define the "radical left" so narrowly that only the Khmer Rouge and North Korean Communist regime fully qualify. But this discussion envisages a much larger and looser set of political experiments. Examples range from Jacobins to anarchists to Bolsheviks and can include various "national liberation" movements. More recent instances such as the Popular Unity government in Chile, South Africa's African National Congress, and the "twenty-first century socialism" of Bolivarian Venezuela might also qualify for inclusion even though their radicalism is not so uncompromising and absolute. To sustain any general argument on our topic this 
diversity must of course be contained within some defining boundary conditions. In this short summary article, radical left movements are about "this worldly" (secular) political transformations. They envisage a frontal break with established hierarchies of authority, and their replacement by a full-scale alternative political order directed towards human emancipation, redistribution, and social inclusion, all within an egalitarian framework.

So how might this emancipatory intention become subject to authoritarian temptations? The easy part is to list the frequent episodes in which emancipatory breakthroughs have produced some dramatic negation of their initial promise. The Jacobin Terror that followed from the overthrow of French monarchism provides the key exhibit. The Soviet revolution in Russia soon produced a Bolshevik counterpart that proved drastically and durably repressive, and that set the standard for leftist takeovers in the twentieth century. Among subsequent confirmations of this sequence the Chavez government in Venezuela was slow to unfold, and far less thorough in its repression, but it now does appear to confirm the basic pattern. So, the emergence of tyranny is clearly a strong possibility when the radical left sweeps to power. But is it an inherent feature of all such revolutionary experiments? And in any case, what is it about the starting point that tends to produce the inverted outcome? These two questions are linked. Explanations for the evolution of radical regimes should distinguish between internal features that are inherent to such endeavors and external reactions that may force them into unwanted desperate measures in order to survive. The strong claim that the radical left is inherently authoritarian rests on identifying necessary characteristics specific to this form of political expression that would lead to authoritarian rule however the rest of the world responded. What features of a successful radical left takeover of state power could make more probable an ensuing large-scale resort to systemic repression? Let us consider the four main lines of argument for this position: i) security interests; ii) destruction of restraints; iii) polarization; and iv) suppression of the market. The first two are wholly internal factors, whereas the last two also invoke responses that may be somewhat external to the radical project.

The most obvious and visible factor has been i) the emergence of a state security bureaucracy with a manifest and vested interest in entrenching its power. A revolutionary breakthrough requires overcoming the security capacities of the outgoing regime. On the one hand this involves the enlistment of wide popular activism to confront and overwhelm the praetorian defenders of the ancient regime. The fall of the Bastille symbolizes the idealism and emancipatory ambition that fires up the radical left. But at the same time the new authorities always need to establish some coherent structure of discipline to 
replace the old order, especially after the turbulence unleashed by the experience of revolutionary change.

Even so, radical left security policies are not narrowly predetermined. The Bolsheviks were very determined to avoid the thermidorean backlash that brought down the Jacobins, so they stressed strong party control over military and their own new repressive forces. In turn later revolutionary movements tried to differentiate themselves from the excesses of Stalinism. For example, Fidel Castro relied more on local civilian "committees for defense of the revolution" and the Sandinistas followed this model. The Khmer Rouge went to the other (genocidal) extreme. Hugo Chavez toward the end of his rule pursued a more hybrid and erratic security policy, although toward the end he may have become increasingly dependent on imported Cuban advisers. Salvador Allende tried unsuccessfully to win over the Chilean military command, a policy that Evo Morales pursued with more (although only partial) success. In summary, although this factor provides the radical left with authoritarian temptations, it is by no means a guarantee that all emancipatory power conquests must lead to unfettered repression.

The second facilitating condition is that when the radicals sweep all obstacles aside they thereby ii) eliminate useful restraints on their own abuse of power. They also allow no legitimate external social space for the corrective salves normally provided through independent feedback, doubt, and criticism. That impedes prudent navigation through the complexities of governing, and raises the incentive for the incumbents to persist with harmful policies in disregard of societal resistance. Independent media, an autonomous legal system, and the sounding board of competitive elections may be inconvenient checks on radical enthusiasms but they also provide healthy feedback that can assist successful governance. Again, radical left regimes face strong temptations to dispense with such guiderails, but here too the historical record contains a variety of responses. The elaborate structures of the contemporary party state in China include many provisions intended to combine flexibility and responsiveness with the underlying stability of authority (a preoccupation that can be traced back to its Confucian and Taoist roots). In its way(and with grave limitations) the Leninist formula for democratic centralism also addressed this problem. Over time, and after much painful experience of "mistakes," many Communist Party regimes have devised more or less workable solutions to this dilemma. In a minority of cases radical left regimes have become completely addicted to repressive solutions, but in general this choice has proven a long-term failure, in part because of the loss of creativity it entails, and also because even the leadership feels threatened by excessively arbitrary rule. Non-communist radicals (such as Julius Nyerere in Tanzania, 
or Chavez in Venezuela) could never rely on such rigid party discipline, and always needed to remain open to feedback from more diverse sources of social expression. Contemporary left-populist movements in Southern Europe (such as Podemos in Spain and Syriza in Greece) were accused by their antagonists of fostering authoritarian projects, but at least to date their performance in office has proven broadly democratic. These are, in any case, two borderline examples given that i) they were left-restorationist projects in societies marked by the prior triumph of the right over the left in a full-scale civil war that had inoculated most left-wing opinion against authoritarian temptations; ii) these parties may have been in office, but were never fully in power - Podemos was in a subordinate alliance with the centrist PSOE, and Syriza's government was always under the thumb of Greece's paymasters in Brussels.

The third factor inclining radical left regimes towards authoritarian solutions is iii) polarization. The root-and-branch nature of the changes they envisage necessarily poses an existential threat to powerful established interests who are almost bound to try to fight back. Whatever the intentions of the losing side, the victorious left is sure to suspect the worst from them, and any intermediate stratum of opinion is liable to be perceived as a potential danger to the revolution. This is an inherently polarized starting point from which to construct a new political order. It provides a strong incentive for at least the more insecure components of the new ruling coalition to opt for authoritarian rather than conciliatory strategies towards its real or imagined oppositions. This is certainly a recurrent feature of radical left political experiments, but here too the analysis needs to be undertaken with care. First, polarization is by no means confined to revolutionary situations. Indeed there are considerably more examples of agitation by privileged strata against imagined or invented revolutionary threats than examples where the threat actually materializes. Contemporary populist politics are suffused with polarizing discourses aimed not at protecting society from genuine revolutions, but rather at distracting dissatisfied groups from effective action to curb elite abuses. Second, once it has become apparent that the radical left really has come to power and is serious about its program, the calculus of consent is sure to shift. Some fractions of the old regime become willing to settle for small reassurances, realizing that their former privileges are irredeemably lost. Diehards become more isolated and easier to detach from the mainstream of political life. Confident and strategically minded radical leftists therefore have an incentive to consolidate their revolutionary gains by extending an olive branch to former opponents. "Everything for those within the Revolution, nothing for those against it" was Fidel Castro's winning formula in the 196os, and most leftist rulers adopt the "Let a Hundred Flowers Bloom" rhetoric at least as a useful tactic, sometimes 
even as a strategy. Here again the authoritarian option maybe tempting, but it is not always and universally compelling.

The fourth and final consideration tending to generate and sustain authoritarian politics in radical left regimes is iv) the suppression of market processes, including the disruption of private property rights. This is most pronounced in Communist regimes, but can also arise when resource rent economies such as that of Venezuela fall under left nationalist control. A longstanding (if extreme) liberal ideological position has been to equate private property ownership with freedom, and state control over the economy with political oppression. On that basis radical left revolutions that substitute price controls and regulated markets for commercial competition are "the road to serfdom." North Korea certainly provides some confirmation that this is possible, but it is far from being a modal case. This ultra-liberal argument differentiates the radical left from all other ideologies and makes it inherently authoritarian, since society is denied market freedoms. A controlled economy does indeed create some extra incentives for authoritarian rule, but here too the connection between socialism and political repression is easily overdone. The Anti-Slavery Society provides one reminder that some kinds of private property need regulating to protect fundamental liberties. A quick glance at the Heritage Foundation's ranking of states by their degrees of economic freedom should serve to warn against too simple a reading. Scandinavian social democracies with excellent anti-authoritarian credentials rate far worse than Singapore or Hong Kong, for example. In a country like South Africa, where so much of the wealth is still owned by the white minority, is it necessarily authoritarian to seek votes for policies of radical property redistribution? The tragedy of Zimbabwe demonstrates that ill-conceived policies of market suppression can certainly destroy the foundations for personal freedom (including the freedom of the poor and dispossessed), but the comparative record of the national liberation movements that came to power across southern Africa provides no easy answer to the challenge of reconciling economic justice with political liberty. On a wider canvas, the "radical left" regimes of China and Vietnam have demonstrated that market processes can be liberalized, and private ownership can be conditionally encouraged, without dismantling the party state and its repressive political accompaniments.

This short overview focuses on the strategic choices made by radical regimes, so it must leave aside such crucial topics as the role of counterrevolutionary forces in driving the radical left into a repressive crouch, or the influence of global forces (ideational, geopolitical, economic, and even juridical) in narrowing or broadening the scope for repression by radical left governments. All it has done is review the four main factors that can help shape the 
strategic choices of successful radical left national governments. Under each heading there are specific incentives that raise the odds on the adoption of authoritarian formulae for rule, but such considerations only shift the probabilities. They do not determine the outcomes. Taken together, all four factors constitute a substantial set of pressures that encourage such governments to rely heavily on repression, at least during extended periods of time. But durable authoritarian regimes rest mostly on other sources of legitimation or justification that also require serious consideration. (Here we refer not only to radical left variants of authoritarianism - fascist governments and theocracies like that of Iran also combine repression with more positive efforts at legitimation, as indeed any regime that aims to last must do.)

As already noted, our concern here is only with radical left regimes, so we can now focus on their specific ways of thinking, and the consequences of these for decisions about repression. The far left draws much of its strength from its conviction that it provides a better alternative to prevalent forms of rule that it considers unjust or intolerable. In the past that referred to hereditary, traditional, and imperial systems of government, but in the current era the main target of the far left is neoliberal capitalist democracy. In the long run the left's key weakness has been its recurrent failure so far to deliver many of the promised better alternatives. It usually achieves improvements in some areas, but at a heavy cost in others. Moreover, the successes of secular (this worldly) movements come to be taken as given, while their failings continue to rankle. This is why left regimes often draw more of their strength from the failures of alternative options than from the enduring popularity of their own achievements.

Admittedly in the present era the Chinese Communist Party can still plausibly argue that it offers a superior long-term formula for government, especially given the evident limitations of "really existing" Western democratic models. But here we are less concerned with current controversies than with underlying theoretical questions. A general distinction can be made between two successive (but overlapping) stages in the legitimating discourse of radical left rulers. Given the long-run liberation agenda of such movements, they often justify resort to coercive methods during a transitional period because at first beneficiaries of the old order are sure to resort to even the most desperate expedients. Considerable time will be needed to re-educate them into acceptance of the new dispensation. While this justification may carry conviction in the early years of a new radical regime, it loses credibility over time, as the uncertainties of the transition fade away.

To maintain continuity and sustain faith in the radical agenda after the period of transition, leftist incumbents require an updated legitimation 
discourse. They cannot just fall back on appeals to tradition or deference to authority of the type deployed by status quo and reactionary regimes. Instead, they must devise a rationale for their ascendancy that offers hope for an emancipatory future in accordance with their rhetoric of transformation. Thus, the Soviet Union promulgated the (highly unreal)Constitution of 1936; in 1956 Chairman Mao proclaimed "let a hundred flowers bloom, a thousand schools of thought contend"; and eventually even the Castro brothers revised and updated the island's "socialist" constitution in order to pass the revolutionary baton on to the next generation. In each of these examples the official doctrine has been that emergency measures could be relaxed and popular participation enhanced, because the new order had become normalized. But mostly in the event repression persisted or indeed intensified (in Russia the Great Terror and the elimination of the Old Bolsheviks followed on directly from the Constitution; in China the hundred flowers campaign was followed by the disastrous Great Leap Forward). Nevertheless, the need to reconcile radical beginnings with long-run, socially legitimate results remains a core issue for such regimes. This largely accounts for Gorbachev's embrace of glasnost and perestroika, and for China's post-Mao positioning. So long as Fidel Castro was supreme commander, the Cuban Revolution policed the boundary between discipline and inclusion on an erratic course set by his speeches; since then a more bureaucratic and sluggish procedure has emerged. Other secular radical left regimes such as Chavista Venezuela and Sandinista Nicaragua still depend on the whims of a top leader. They too are at risk of eventual total eclipse if they abandon the effort to vindicate their foundational myths.

These long-term emancipatory features of radical left politics both generate regime resilience and simultaneously fuel top-level factional conflicts that can be resolved only through zero-sum confrontations. The first generation of radical cadres may share a common heritage of solidarity and joint struggle that unifies them despite programmatic disagreements. But subsequent cohorts of leftist leaders and ideologues are more likely to clash among themselves over control of their continuing project. It is often the most talented and strategically situated of rising radicals who attract the greatest loyalty, but also intense factional hostility. Therefore, the coercive methods initially deployed against counter-revolutionaries are often redeployed against fresh enemies within the ruling elite. Although personal rivalries are critical here, ideological battles are also involved. The underlying authoritarian temptation arises in part from ideational and policy-based disagreements. Losers need to be disqualified for their doctrines and/or their disloyalties, not just their tactical miscalculations. Likewise, the victors in these factional struggles need to convince their militants that the correct radical line had been vindicated against heresy or 
betrayal. In short, ideology and not just personal interest is required to legitimize each step in the evolution of radical rule. A key source of authoritarian temptation here arises because of genuine high-level disagreements about how best to serve the emancipatory purposes of the movement.

Once in power radicals face difficult choices concerning the secularizing and emancipatory agenda they have set themselves. Two key issues tend to recur. First, radicals may be confident that in the long run the next generation will enjoy the full benefits of their emancipation, and will therefore provide enduring support to the new regime. But at the outset the current generation will have to endure notable hardships. So, although their outlook is "this worldly," these radicals will need to have faith in the value of their promises, and will tend to discount current suffering by comparison to expected future rewards. Psychologically, therefore, this value orientation can come to resemble a religious outlook, despite its theoretical secularism. Second, in the course of their transformational project a minority of true believers, ready for any sacrifice in order to serve the cause, will emerge and be pitted against the larger community of potential beneficiaries, whose immediate concerns are less central to the project than the existential needs of their militants and loyalists. If not everyone can be emancipated at the same time, then the politically advanced minority will have a claim to priority. The uncommitted and those of a different initial persuasion come to be disvalued in the short term, whatever the regime's intentions concerning universal emancipation in due course. The authoritarian temptations arising from these two considerations are self-evident.

A third difficulty is all too likely to arise from these first two. Even within the ranks of the committed there are bound to be disagreements concerning the correct balance to strike between faith and deeds, between present compromises and future objectives, and between the leadership and the social base. How are emancipatory, inclusionary, and egalitarian principles to be interpreted, reconciled, and implemented in practice? Once the incumbent leadership has made its choices on these troubling issues it must project unity - and silence inner voices of dissent. To some extent this may be achieved by appeals to loyalty and shared values, but the elite will always generate some doubters. If they hold out, or can no longer be trusted to conform, they will become too dangerous to tolerate. The syndrome by which "the revolution devours its children" arises from this dynamic, and accounts for most of the most egregious authoritarian excesses of many radical regimes. Even so, the pursuit of a transformational agenda still requires a persuasive discourse, and long-term success still depends upon recruiting new militants with the discipline, commitment, and innovative capacity to update and then carry forward the movement's 
emancipatory prospectus. Consequently, as each radical left regime strives to reproduce itself over time, it will undergo successive seesawing between the requirements of unity and discipline and the search for new sources of creativity, experimentation, and adaptive learning.

This seesawing argument involves taking seriously the ideas that are claimed by the radical left as the motivation for its activism. In contrast to other rival political movements, their doctrines are transformational (therefore not reactionary or traditionalist), and secular (therefore not theocratic or other worldly). What they have in common is that they can be used to justify the conquest of power (not merely reforms within an accepted status quo). It is that radical break with the existing order that facilitates authoritarian excesses in all three cases.

But there is also, of course, an alternative account of these dynamics. It dismisses the ideational motivations of the insurgents as mere rhetoric - or at best naïve illusions quickly surpassed once they find power within their grasp. On this view, whatever the radicals may claim about their emancipatory and secular intentions, the Hobbesian realities of post-insurrectionary instability are sure to overwhelm the left's initial programmatic ideals. As the new elite struggles for survival in a disordered society, negative selection will promote the rise of the most ruthless, and the shattering of utopian expectations will result in unadorned repression. Beyond question the comparative history of revolutionary processes provides at least intermittent evidence in support of this power-corrupting interpretation. As has recently been demonstrated by the 45th president of the United States, it is not only radical left anti-system politicians who may respond to opposition by escalating polarization and flirting with authoritarian solutions. Since even Trumpian ideas help account for the energy and direction of his movement, it is surely clear that more ambitious and coherent radical left ideas also require due consideration. It would be an error to dismiss this factor without further study as invariably no more than empty rhetoric. The existence of counter-currents and adverse examples does not rule out of court the possibility that at least some of the more durable radical left experiments have in fact derived resilience from the ideas that are said to inspire them.

This brief and schematic overview of how radical left ideas may be adjusted to the challenges of political success has underlined the scope they contain for authoritarian experimentation. Such temptations are at least partially rooted in the discursive logic of the radical position. But there is also a countervailing potential at work. The legitimizing claims of the theorists will periodically need to be adjusted and reinterpreted, but if the new regime is to last and to win voluntary assent from futures generations (rather than to disintegrate and 
be replaced by a restoration), it will have to seek some doctrinal continuities. That remains a serious issue for some of the most durable experiments in radical-secular emancipatory politics - as can be seen today, for example in Cuba and South Africa, and as the Chinese Communist Party celebrates its centennial anniversary.

Such legitimation strategies will contain three main components: i) reaffirming and updating the regime's emancipatory origins; ii) downplaying/excusing authoritarian "deviations"; iii) projecting future prospects for emancipatory inclusion.

When radical left ideas and aspirations are taken seriously it becomes possible to analyze this type of regime more dispassionately, and to promote dialogue with their rulers from outside their own frame of assumptions. This can provide a balanced understanding of the authoritarian risks they face (risks also present in other regime types) and thus to explore possible common ground with them over such underlying values as human emancipation, inclusive governance, and the promotion of equality. In principle, after all, such aspirations are not restricted to the radical left, but on the contrary have near-universal appeal.

https://homeuseromsmy.sharepoint.com/:w:/g/personal/laurencewhitehead_ homeuseroms_onmicrosoft_com/ERNvgI_qnxJBkM-oCHJJ6TYBhB8OaEKU mJdG3gliAfvO $7 \mathrm{w}$ ? $=$ =aUsztU. 